УДК 628.16:547.495.1:547.288.1

${ }^{[0000-0002-5619-7733]}$ I. М. Демчук, к.т.н., асистент, e-mail: ivannademcuk19@gmail.com

${ }^{[0000-0001-5287-3733]}$ Г. С. Столяренко, д.m.н., професор,

завідувач кафедри хімічних технологій та водоочищення ЧДТУ,

${ }^{[0000-0001-7113-9892]}$ В. М. Вязовик, д.т.н., дочент

Черкаський державний технологічний університет

б-р. Шевченка, 460, м. Черкаси, 18006, Україна

\title{
СИНТЕЗ ГІДРАЗИНУ \\ ЯК МЕТОД ОЧИЩЕННЯ СТОКІВ ВИРОБНИЦТВА КАРБАМІДУ
}

У зв'язку з наявністю «вузьких місиь» в існуючих технологіях виробництва карбаміду пошук перспективних напрямів удосконалення виробництва є актуальною задачею сьогодення.

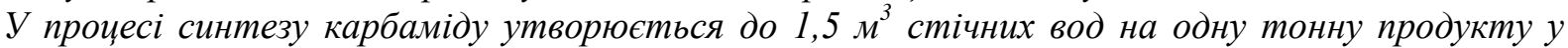
вигляді конденсату сокової пари. Для очищення стоки направляють на гідроліз карбаміду з наступною десорбиією аміаку та вуглекислого газу. Сполуки зв'язаного азоту для доочищення направляють на біологічні очисні споруди, ефективність яких не перевищує 80 \%. Вищезазначений спосіб очищення стоків потребує високих витрат електричної та теплової енергії. Гідроліз та десорбиія конденсату сокової пари оцінюються як сучасний і найбільш перспективний спосіб утилізаиії стоків, який впроваджений на всіх установках синтезу карбаміду.

У роботі розглянуто новий метод утилізаиії азотовмісних конденсатів виробницттва карбаміду шляхом їх використання як вторинної сировини для синтезу гідразину. Проведено дослідження процесу синтезу гідразину в електромагнітному реакторі синтезу, а саме: вивчено вплив швидкості потоку реакиійної суміші, що надходить в електромагнітний реактор синтезу $\mathrm{N}_{2} \mathrm{H}_{4}$, на вихід продукту. Встановлено залежність значення ступеня перетворення азоту загального в $\mathrm{N}_{2} \mathrm{H}_{4}$ від швидкості потоку реакційної суміші в мультимодовий електромагнітний реактор синтезу гідразину. Проведено математичну обробку експериментально отриманих даних з метою встановлення оптимального режиму потоку. Підтверджено результати розрахунку математичної моделі кінетики хімічних реакиій, що ініціюються електромагнітним нагрівом, шляхом вирішення системи рівнянь Ареніуса і теплопровідності за неявною схемою. Підтверджено, що більш ефективним є ииклічний нагрів. У ході досліджень встановлено, що проиеси синтезу гідразину проходять у дифузійній області. Виявлено, що відсутність насосів, хоча й знижує енерговитрати установки синтезу гідразину з вторинної сировини, але при впровадженні у виробництво ускладнює процес його контролю через самовільну регуляцію швидкості відведення синтез-розчину з зони реакиії, викликаної ефектами внутрішнього ерліфту газом $\mathrm{CO}_{2}$ та імплозії.

Ключові слова: гідразин, карбамід, аміак, синтез, конденсат, електромагнітний реактор.

Вступ. Ефективність очищення стічних вод на біологічних очисних спорудах від сполук зв'язаного азоту в середньому по Україні становить $77 \%$ при середній концентрації амонійного азоту на вході 30 мг/дм ${ }^{3}$ [1]. Таким чином, щороку в поверхневі водні об'єкти України потрапляє близько 20000 тонн зв'язаного Нітрогену.

Карбамід виробляють $3 \mathrm{NH}_{3}$ i $\mathrm{CO}_{2}$ через процес утворення карбамату амонію. Зазвичай використовують процеси:

a) 3 рециркуляцією вуглеамонійних солей у розчині або у вигляді суспензії, його ще називають синтезом з рідинним рециклом; б) селективного вилучення газової фази одного $з$ компонентів і роздільного повернення $\mathrm{NH}_{3}$ i $\mathrm{CO}_{2}$ в цикл - синтез з газовим рециклом.

Найпоширенішими $є$ схеми $з$ рідинним рециклом [2].

У зв'язку з наявністю «вузьких місць» в існуючих технологіях виробництва карбаміду пошук перспективних напрямів удосконалення виробництва $є$ актуальною задачею сьогодення [3-4].

Багато робіт спрямовано на пошук способів покращення якості готового продукту (збільшення статичної та динамічної міцності гранул, зменшення гігроскопічності, змен- 
шення злежування та втрати сипучості) внаслідок удосконалення грануляторів і приляторів, а також введенням домішок (наприклад, у плав вводять карбамід-формальдегідний концентрат) або обробкою гранульованого продукту кондиціонуючими домішками [5-8]. Вищезазначені фактори, безумовно, впливають на остаточну вартість продукту, але для суттєвого збільшення прибутку потрібно інтенсифікувати та раціоналізувати процес виробництва.

Відповідно до рішення Європейської економічної комісії Організації Об'єднаних Націй і Декларації про маловідходну і безвідходну технології в процесі вибору напряму шляхів раціоналізації виробництва варто звертати увагу на вторинні ресурси - як енергетичні, так і сировинні.

Синтез карбаміду складається 3 шести основних технологічних стадій:

1. Підготовка сировини, в яку входить очищення $\mathrm{CO}_{2}$ від горючих домішок та компримування.

2. Синтез карбаміду із $\mathrm{NH}_{3}$ та $\mathrm{CO}_{2}$.

3. Рецикуляція.

4. Випаровування розчину карбаміду.

5. Гранулювання.

6. Очищення рідких та газових відходів (абсорбція, десорбція, гідроліз).

Раціоналізувати процес синтезу досить складно. Тому основним напрямом обрано мінімізацію енерговитрат.

Як об'єкт дослідження обрано стадію очищення рідких та газових відходів, а саме: процеси гідролізу та десорбції аміачної води конденсату сокової пари. Стоки утворюються в конденсаторах після вакуум-випарних апаратів. У процесі випаровування відбувається концентрування новоутвореного $72 \%$ розчину карбаміду до концентрації не менш ніж до $98 \%$ карбаміду в плаві [9] з утворенням пари, що містить продукт та компоненти синтезу.

Саме в процесі конденсації сокової пари утворюється основна частина стічних вод виробництва карбаміду, котрі направляють на стадію гідролізу, де при підвищених температурах $\left(\sim 200{ }^{\circ} \mathrm{C}\right)$ відбувається розкладання залишкового карбаміду $з$ наступною десорбцією, яка проходить при температурі $110 \div 140{ }^{\circ} \mathrm{C}$.

Характеристику конденсату сокової пари наведено в таблиці 1. В таблиці вказано обсяги утворення конденсату сокової пари від 0,7 до $1,5 \mathrm{~m}^{3} / \mathrm{T}$ карбаміду, що в реальних умовах, при виробництві карбаміду за стрипінг-процесом продуктивністю 330000 т/рік перетворюється на $222000 \sim 500000$ м³/рік рідких відходів.

У роботі [10] пораховано, що при ліквідації стадії десорбції та гідролізу можна заощадити на статті енерговитрат близько $2,4 \%$ від собівартості карбаміду.

Цінність конденсату сокової пари обумовлена низьким вмістом розчинених металів (до $0,01 \%$ масової частки), відсутністю органічних речовин і розчинених хлорид-, нітрат-, сульфат- та фосфат-іонів [11].

У роботах [12-14] запропоновано використовувати конденсат сокової пари як сировину для синтезу гідразину з використанням електромагнітного синтезу гідразину.

Гідразин або діамін $\left(\mathrm{N}_{2} \mathrm{H}_{4}\right)$ має широкий спектр використання, ознайомитися 3 яким можна у роботах [15-17].

У XXI ст. структура споживання гідразину розподіляється таким чином: виробництво пестицидів - $40 \%$ від загального обсягу споживання; виробництво піноутворюючих агентів - $30 \%$; виготовлення речовини для водопідготовки - $14 \%$; інші сфери застосування - $17 \%$ [13].

Проаналізовано також інші галузі використання основних компонентів конденсату сокової пари. У роботі [18] зазначено, що карбамід може бути використано для виробництва карбамідоформальдегідних смол; для виготовлення меламіну та меламіноформальдегідних смол; для отримання органічних карбонітів (гліцеролкарбонату, етиленкарбонату); для виробництва косметичних та лікарських засобів. Проаналізувавши вищезазначені процеси, виявлено, що низькоконцентровані водні розчини, які містять і амонійний азот, використовуватися як сировина не можуть.

На сьогоднішній день виробництво гідразину та його похідних в Україні припинено. Запропоноване у роботах [12-14] раціоналізаторське рішення використання конденсату сокової пари виробництва карбаміду для синтезу гідразину, крім екологічної перспективи (зменшення азотовмісних стоків), має ще й економічні вигоди як для агрегату синтезу карбаміду, так і для виробництва гідразину внаслідок дії закону попиту.

Основною сировиною для синтезу $\mathrm{N}_{2} \mathrm{H}_{4}$ $\epsilon$ аміак (синтез за методом Рашига 3 використанням гіпохлориту натрію) та карбамід (синтез за методом Хофмана) [13]. 
Таблиця 1 - Характеристика рідких відходів виробництва карбаміду

\begin{tabular}{|c|c|c|}
\hline № п.п. & Найменування ознаки & Показник та (чи) значення \\
\hline 1 & Якісний та кількісний склад & $\begin{array}{l}\text { концентрація } \mathrm{NH}_{3} \text { до } 5 \text { \% мас.; } \\
\text { концентрація } \mathrm{CO}_{2} \text { до } 3,5 \% \text { мас.; } \\
\text { концентрація } \mathrm{CO}_{2}\left(\mathrm{NH}_{2}\right)_{2} \text { до } 2,5 \% \text { мас.; } \\
\text { концентрація } \mathrm{C}_{2} \mathrm{H}_{5} \mathrm{~N}_{3} \mathrm{O}_{2} \text { до } 0,5 \% \text { мас.; } \\
\text { концентрація } \mathrm{H}_{2} \mathrm{O}-\text { решта }\end{array}$ \\
\hline 2 & $\begin{array}{l}\text { Теоретичний обсяг утворення конденсату } \\
\text { сокової пари }\end{array}$ & не менше 0,33 м³ / 1 т карбаміду \\
\hline 3 & $\begin{array}{l}\text { Практичний обсяг утворення конденсату } \\
\text { сокової пари }\end{array}$ & $0,7 \div 1,5$ м $^{3} / 1$ т карбаміду \\
\hline 4 & Стадії очищення & $\begin{array}{l}\text { попереднє очищення (гідроліз і десорбція); } \\
\text { остаточне (біологічне доочищення на } \\
\text { установках нітри-денітрифікації) }\end{array}$ \\
\hline 5 & $\begin{array}{l}\text { Ефективність попереднього } \\
\text { очищення від сполук зв'язаного азоту }\end{array}$ & $\sim 77 \%$ \\
\hline 6 & $\begin{array}{l}\text { Ефективність остаточного очищення від } \\
\text { сполук зв'язаного азоту }\end{array}$ & $\sim 98 \%$ \\
\hline 7 & $\begin{array}{l}\text { Вартість утилізації конденсату сокової } \\
\text { пари за умови обсягу утворення стоків } \\
\text { на рівні } 0,7 \text { м³/ } \mathrm{CO}\left(\mathrm{NH}_{2}\right)_{2}\end{array}$ & 130 грн (5 \$) / 1 т карбаміду \\
\hline
\end{tabular}

У дослідженнях, що описані у роботах [11-14], встановлено можливість використання конденсатів сокової пари виробництва карбаміду, котрі в своєму складі містять суміш низькоконцентрованих розчинів амідного та амонійного азоту, в процесі синтезу $\mathrm{N}_{2} \mathrm{H}_{4}$. Як альтернативне джерело енергії, яку потрібно надати системі, використано хвильовий реактор. У роботах експериментально доведено утворення гідразину за умов синтезу останнього зі стоків у електромагнітному ректорі синтезу.

У роботі [19] розглянуто математичну модель кінетики хімічних реакцій, що проходять під дією електромагнітного випромінювання, за рахунок розв'язання системи рівнянь Ареніуса і теплопровідності методом наближень за неявною схемою за умови прийняття базових значень інтенсивності випромінювання, теплопровідності сировини, об'ємної теплоємності та ін. За результатами розв'язання цієї системи рівнянь зроблено висновок про те, що надмірне збільшення температури в області прореагованих речовин $\epsilon$ небажаним і знижує вихід продукту.

Мета роботи - дослідження процесу синтезу гідразину в електромагнітному реакторі синтезу, а саме: вивчення впливу швидкості потоку реакційної суміші, що надходить в електромагнітний реактор синтезу $\mathrm{N}_{2} \mathrm{H}_{4}$ на вихід продукту.

Виклад основного матеріалу дослідження. Для проведення дослідів використано реальні розчини. Використання модельних розчинів ускладнене наявністю у розчиннику $\left(\mathrm{H}_{2} \mathrm{O}\right)$ домішок - металів, особливо іонів міді. Порівняльну гістограму аналізу зразків розчинника на вміст металів, визначених за допомогою атомно-абсорбційних методів аналізу, зображено на рисунку 1 .

Саме внаслідок підвищення нуклеофільності гетероатома N (а-ефекту) реакційна здатність гідразину аномально висока. Гідразин - сильний відновник. Якщо не усунути вплив домішок, буде відбуватися миттєва деструкція новоутвореного гідразину [20-22]. 


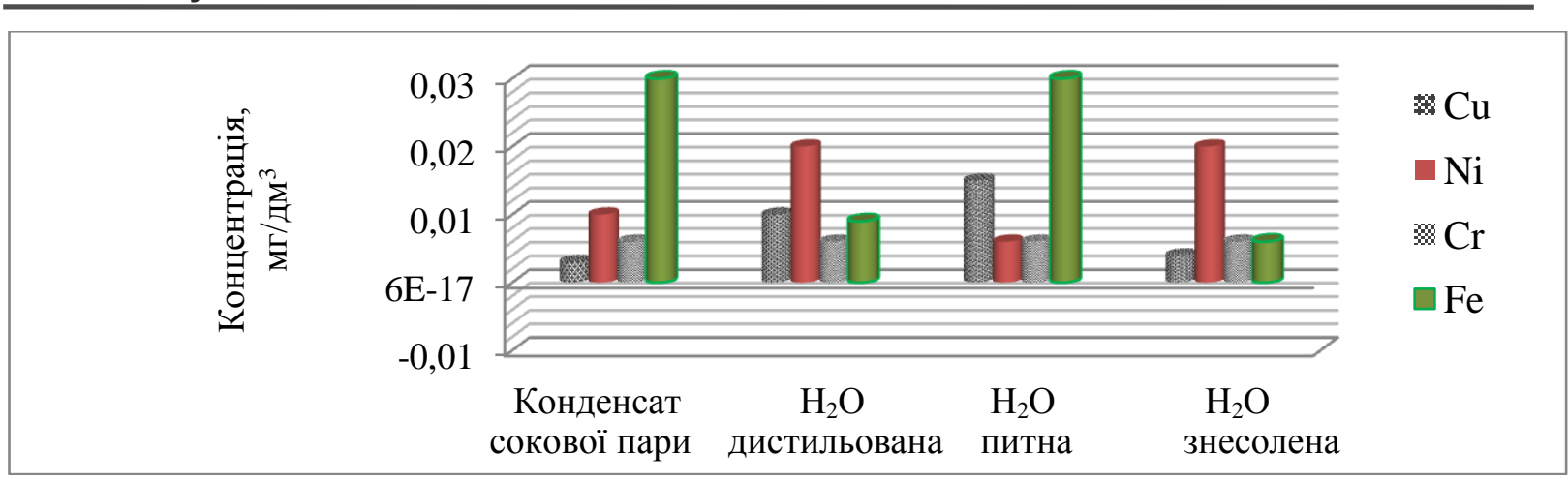

Рисунок 1 - Порівняльна гістограма вмісту металів (Cu, $\mathrm{Ni}, \mathrm{Cr}, \mathrm{Fe})$ у зразках розчинника та стічній воді виробництва карбаміду

Методика проведення синтезу

Синтез проведено з використанням модельної установки синтезу періодичної дії. Основним обладнанням $\epsilon$ мультимодовий електромагнітний реактор синтезу $\mathrm{N}_{2} \mathrm{H}_{4}$ об'ємом 0,1 дм³. Для дозування компонентів синтезу використано напірний бак. Швидкість потоку регулюється запірною арматурою за місцем за допомогою фіксування об'ємних витрат. Всі компоненти перед подачею в реактор синтезу $\mathrm{N}_{2} \mathrm{H}_{4}$ змішуються в реакторі ідеального змішування. Блок-схема представлена на рисунку 2.

Перед початком синтезу обов'язково треба визначити кількісний склад зразка стічної води до стадії десорбції та гідролізу на вміст основних компонентів. Ця дія обумовлена детермінацією вмісту основних компонентів у сировині $\left(\mathrm{NH}_{3} ; \mathrm{CO}\left(\mathrm{NH}_{2}\right)_{2} ; \mathrm{C}_{2} \mathrm{H}_{5} \mathrm{~N}_{3} \mathrm{O}_{2}\right)$ залежно від параметрів технологічного режиму синтезу карбаміду, а особливо стадії вакуум-випаровування.

Метод вимірювання масової частки аміаку у конденсаті сокової пари - титрометричний, грунтується на нейтралізації аміаку розчином соляної кислоти в присутності індикатора метилового червоного або бромфенолового синього.

Метод визначення вмісту біурету в пробі - фотоколориметричний, грунтується на взаємодії біурету з лужним розчином сульфату міді з утворенням комплексної сполуки, забарвленої у синій колір, причому аміак, наявність якого заважає визначенню концентрації біурету, попередньо відганяється 3 ацетоном або метанолом.

Метод вимірювання масової частки карбаміду у стічній воді - титрометричний, грунтується на попередній мінералізації амідного Нітрогену сірчаною кислотою до аміачного Нітрогену, при подальшій взаємодії якого 3 формальдегідом виділяється сірчана кислота,

(C) I. М. Демчук, Г. С. Столяренко, В. М. Вязовик, 2020 DOI: 10.24025/2306-4412.1.2020. 19111 котра титрується розчином лугу в присутності індикатора.

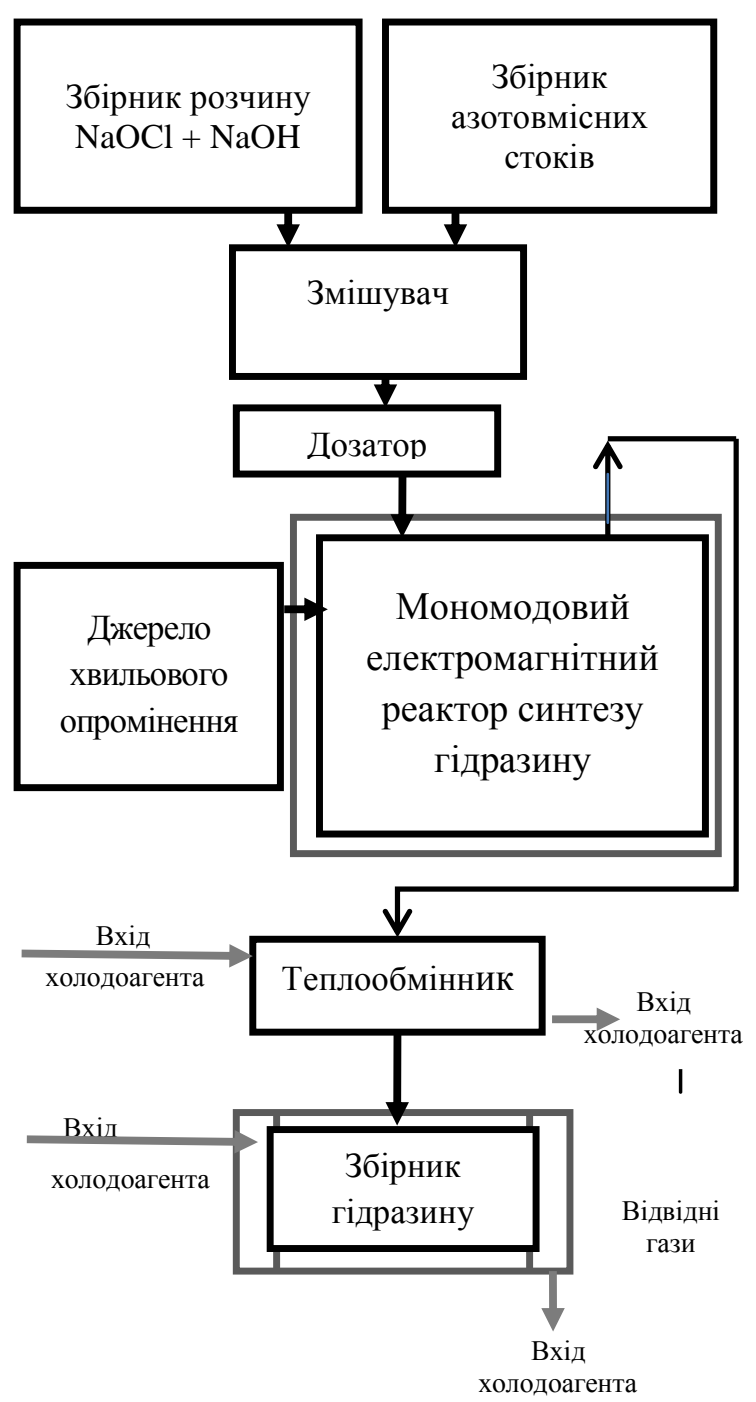

Рисунок 2 - Блок-схема синтезу гідразину

Гіпохлорит натрію, який використовується в процесі синтезу $\mathrm{N}_{2} \mathrm{H}_{4},-$ нестійка сполука. Він легко розкладається 3 виділенням кисню. Перед подачею компонентів у змішувач проводиться визначення вмісту активного 
хлору в $\mathrm{NaClO}$. Метод визначення масової частки $\mathrm{Cl}_{2}$ - титрометричний, грунтується на взаємодії йодистого калію 3 гіпохлоритом 3 наступною нейтралізацією йоду, що виділився, тіосульфатом натрію.

Для збереження оптимальних співвідношень компонентів у суміші перед змішуванням проводяться розрахунки. Також готується лужний розчин гіпохлориту натрію. Для цього в гіпохлорит додається їдкий натрій з концентрацією основного компонента $(\mathrm{NaOH})$ 98,5\%.

Реактор перетворення стоків у гідразин піддається дії електромагнітних хвиль довжиною від 1 мм до 1 м (частота > 300 МГц). Мікрохвильове опромінення поглинається речовинами. Механізми нагріву речовин відрізняються від процесів конвекції чи теплопередачі, хоча ці процеси мають місце при мікрохвильовому нагріві. Під дією електромагнітного опромінення розігрів відбувається за рахунок міграції іонних ізотопів або за допомогою обертання дипольних ізотопів (дипольний поляризаційний механізм). Внаслідок вищезазначених процесів змінюється енергія основних станів молекул. Варто відзначити, що у мікрохвильовому полі електрична складова поля коливається 3 дуже великою швидкістю. Нагріву піддаються зазвичай полярні речовини. Сильне коливання, яке викликано циклічною переорієнтацією молекул, приводить до підвищення температури середовища.

Явище нагріву матеріалів мікрохвильовим опроміненням використовується для сушіння, прокалювання, термічного розкладання, каталізу і передачі теплоти рідким або газоподібним реагентам. У хімічній технології мікрохвильове опромінення не має великого спектра застосування. Його здебільшого застосовують для інтенсифікації енергетичного i масового обміну в процесах ректифікації, дегідрування, термічного розкладання карбонатів. Так, наприклад, електромагнітний реактор запропоновано використовувати в процесі глибокої переробки нафти і нафтопродуктів на основі технології радіаційно-хвильового крекінгу [20].

У роботі [14] встановлено, що проводити математичне моделювання процесу синтезу $\mathrm{N}_{2} \mathrm{H}_{4} 3$ конденсату сокової пари 3 використанням електромагнітного реактора синтезу неможливо за рахунок стохастичності системи.

Оскільки конструкція розробленого апарату виключає будь-яке втручання 3зовні, то регулювати швидкість відведення компонентів із зони реакції неможливо. Це явище саморегуляції швидкості відведення компонентів синтезу із зони реакції обумовлено нерівномірністю розподілу хвильової енергії в реакційній зоні. Синтез-розчин транспортується самовільно лише у випадку досягнення заданого діапазону температур, при якому i відбувається синтез гідразину. Самовільне відведення реакційної суміші 3 новоутвореним гідразином ініціюється ефектом імплозії та ефектом внутрішнього ерліфту $\mathrm{CO}_{2}$, який додатково виділяється в процесі синтезу $\mathrm{N}_{2} \mathrm{H}_{4}$. Реакційна суміш 3 електромагнітного реактора синтезу гідразину, проходячи теплообмінник типу «труба в трубі», охолоджується та надходить у збірник розчину $\mathrm{N}_{2} \mathrm{H}_{4}$, де підтримується температура, не вища $20{ }^{\circ} \mathrm{C}$.

В'язкість реакційної суміші до початку синтезу гідразину $\sim 1,8 \mathrm{~m}^{2} / \mathrm{c}$. Температура синтезу становить $93 \div 95^{\circ} \mathrm{C}$. Співвідношенням $\mathrm{NaClO}$ (в перерахунку на $\mathrm{Cl}_{2}$ ) до $\mathrm{N}$ загального $=0,47$ масових часток.

Як визначальний параметр ефективності впливу швидкості подачі реакційної суміші в реактор синтезу гідразину обрано зміну концентрації гідразину у синтез-розчині, яка визначена фотометричним методом. Результати серії дослідів, що проведені для встановлення залежності виходу $\mathrm{N}_{2} \mathrm{H}_{4}$ від швидкості подачі реакційної суміші в мультимодовий електромагнітний реактор синтезу гідразину наведено в таблиці 2.

Таблиця 2 - Значення залежності концентрації гідразину в синтез-розчині від швидкості потоку реакційної суміші, що надходить зі збірника реакційної суміші в мультимодовий електромагнітний реактор синтезу гідразину

\begin{tabular}{|c|c|}
\hline $\begin{array}{c}\text { Значення швидкості } \\
\text { потоку реакційної } \\
\text { суміші, що подається } \\
\text { в реактор синтезу } \\
\text { гідразину, м }\end{array}$ & $\begin{array}{c}\text { Концдентрація } \\
\text { новоутвореного } \\
\mathrm{N}_{2} \mathrm{H}_{4} \text { в синтез- } \\
\text { розчині, } \\
\% \text { масових часток }\end{array}$ \\
\hline $7,92 \cdot 10^{-4}$ & 0,112 \\
\hline $14,04 \cdot 10^{-4}$ & 0,118 \\
\hline $20,52 \cdot 10^{-4}$ & 0,1065 \\
\hline $27,36 \cdot 10^{-4}$ & 0,1065 \\
\hline $57,60 \cdot 10^{-4}$ & 0,105 \\
\hline $68,40 \cdot 10^{-4}$ & 0,105 \\
\hline $82,80 \cdot 10^{-4}$ & 0,104 \\
\hline $187,20 \cdot 10^{-4}$ & 0,106 \\
\hline $244,80 \cdot 10^{-4}$ & 0,105 \\
\hline $320,40 \cdot 10^{-4}$ & 0,105 \\
\hline
\end{tabular}


Проведено регресійний аналіз даних, наведених у таблиці 2, графічне вираження якого зображено на рисунку 3 . Для зручності обробки даних значення швидкості потоку взяті у розмірності, не притаманній системі $\mathrm{Si}$, a саме у $\mathrm{cm}^{3} / \mathrm{c}$.

Після проведення апроксимації експериментально отриманих даних встановлено величину достовірності апроксимації, яка становила 0,5 . Низька величина достовірності логарифмічної апроксимації пояснюється відсутністю приведення даних до спільного знаменника по значенню вмісту азоту загального в конденсаті сокової пари. Концентрація азоту коливалася в межах від 3,241 до 4,228 \% масових часток.

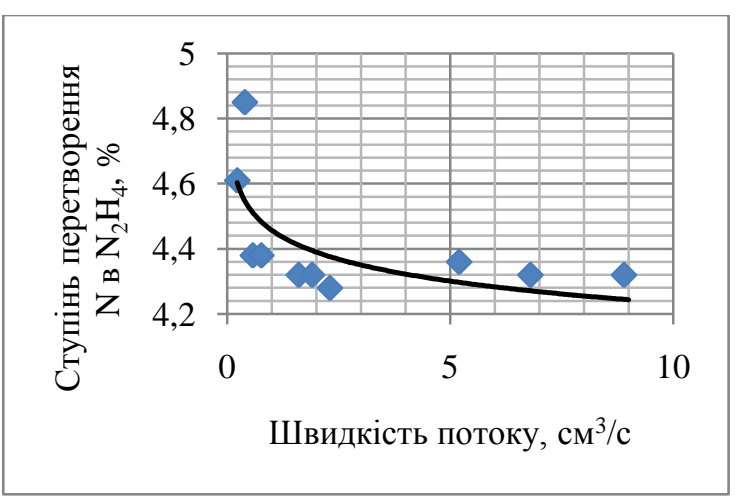

Рисунок 3 - Залежність значення ступеня перетворення азоту загального в $\mathrm{N}_{2} \mathrm{H}_{4}$ від швидкості потоку реакційної суміші в мультимодовий електромагнітний реактор синтезу гідразину

Математичне вираження значення залежності ступеня перетворення азоту загального в $\mathrm{N}_{2} \mathrm{H}_{4}$ від швидкості потоку реакційної суміші в мультимодовий електромагнітний реактор синтезу гідразину представлено рівнянням (1):

$$
\mathrm{C} \Pi=-0,0969424 \cdot \ln (\mathrm{v})+4,4566945,
$$

де $\mathrm{CП}-$ ступінь перетворення азоту загального в $\mathrm{N}_{2} \mathrm{H}_{4}, \%$;

$\mathrm{v}$ - швидкість потоку реакційної суміші в мультимодовий електромагнітний реактор синтезу гідразину, $\mathrm{cm}^{3} / \mathrm{c}$.

При дослідженні функції CП(v) в заданому діапазоні швидкості потоку, який визначається межами від $3,6 \quad 10^{-4}$ до $3,6 \cdot 10^{-2} \mathrm{~m}^{3} /$ год (кількість кроків наближення = 200), рівняння (1) набуває вигляду

$$
\mathrm{C} \Pi(\mathrm{v})=-0.0969424 / \mathrm{v} \text {. }
$$

(C) I. М. Демчук, Г. С. Столяренко, В. М. Вязовик, 2020 DOI: $10.24025 / 2306-4412.1 .2020 .19111$
В результаті дослідження цієї функції встановлено відсутність нулів функції та екстремумів.

Досліджуючи функцію, виражену рівнянням (1), за умови значення верхньої межі швидкості потоку реакційної суміші в мультимодовий електромагнітний реактор синтезу $\mathrm{N}_{2} \mathrm{H}_{4}$, що дорівнює $7,2 \mathrm{~m}^{3} /$ год при кількості кроків наближення, що дорівнює 2000, встановлено відсутність екстремумів та нулів функції.

Однак стверджувати, що збільшення швидкості потоку реакційної суміші в реактор синтезу гідразину до $7,2 \mathrm{~m}^{3} /$ год не вплине на ступінь перетворення недоречно, адже математична модель дає змогу лише припустити той чи інший розвиток подій. Варто зазначити, що при збільшенні швидкості потоку зменшиться вплив мікрохвильового опромінення, а як наслідок - може суттєво знизитися температура синтезу. Відповідно до літературних даних [10-14] синтез гідразину 3 суміші амідного та амонійного азоту виражено ендотермічністю процесу, тому він не буде відбуватися за низьких температур. Зазначено, що реакція нейтралізації аміаку та карбаміду, які наявні в конденсатах сокової пари, гіпохлоритом натрію - екзотермічна, але іiї теплоти недостатньо для автотермічності процесу.

Після аналізу експериментальних досліджень зроблено наступні висновки:

1. За результатами математичної обробки отриманих даних, внаслідок відсутності нулів та екстремумів функції залежності ступеня перетворення азоту загального в гідразин, можна стверджувати про відсутність оптимального режиму потоку.

2. Швидкість синтезу не залежить від швидкості подачі реакційної суміші в мультимодовий електромагнітний реактор синтезу $\mathrm{N}_{2} \mathrm{H}_{4}$.

3. Надмірне зростання швидкості подачі синтез-розчину в електромагнітний реактор синтезу (понад $2 \mathrm{~cm}^{3} / \mathrm{c}$ ) призводить до зменшення часу перебування синтез-розчину в зоні дії хвильового опромінення і до зниження температури синтезу, що $є$ небажаним.

4. Самовільна регуляція швидкості відведення синтез-розчину із зони реакції, викликана ефектом внутрішнього ерліфту газом $\mathrm{CO}_{2}$ та ефектом імплозії, призводить до нерегульованості процесу.

5. Відсутність насосів зменшує енерговитрати установки синтезу гідразину 3 вто- 
ринної сировини, але при впровадженні у виробництво ускладнює процес його контролю. Однак $є$ перспектива майбутнього дослідження процесів, що відбуваються під дією хвильового опромінення, для можливості їх подальшого моделювання та контролювання.

6. Експериментально отримані дані, представлені в таблиці 2, підтверджують результати розрахунку математичної моделі кінетики хімічних реакцій, що ініціюються електромагнітним нагрівом, описаної у роботі [19]. Тобто більш ефективним є циклічний нагрів. При збільшенні часу перебування реакційної суміші в реакторі синтезу під дією мікрохвильового опромінення знижується концентрація основного компонента.

7. У ході досліджень встановлено, що процеси відбуваються не в кінетичній області, для якої було проведено розв'язок систем рівнянь, представлених у роботі [19], а в дифузійній.

Перспективи подальшого розвитку у цьому напрямі. Планується збільшення концентрації гідразину (ступеня перетворення загального азоту в кінцевий продукт) шляхом детермінації параметрів синтезу гідразину 3 конденсатів сокової пари до стадії десорбції та гідролізу карбаміду.

\section{Список використаних джерел}

[1] Наиіональна доповідь про стан навколищнього природного середовища в Украйні в 2007 рочі, Київ, 2008.

[2] Ю. А. Сергеев, Н. М. Кузнецов, и А. В. Чирков, Карбамид. Свойства, производство, применение: монография. Нижний Новгород: Кварц, 2015.

[3] С. В. Островский, "Совершествование технологической схемы производства карбамида с целью снижения производственных потерь карбамида и сырья", Вестник Пермского национального исследовательского политехнического университета. Химическая тихнология и билотехнология, т. 9, с. 5-12, 2009.

[4] В. И. Петров, Р. Р. Мадьяров, Р. Р. Хайрулин, и И. М. Аюпов, "Анализ технологических схем производства карбамида", Вестник технологического университе$m a$, т. 18, № 8, c. 148-150, 2015.

[5] I. Shingareva, and C. Lizarraga-Celaya, Solving nonlinear partial differential equa-

(C) I. М. Демчук, Г. С. Столяренко, В. М. Вязовик, 2020 DOI: 10.24025/2306-4412.1.2020. 19111 tions with Maple and Mathematica: textbook. New York: Springer Wien, 2011.

[6] М. С. Скиданенко, В.И.Склабинский, и Н. П. Кононенко, "Исследование процесса истечения струи жидкости из отверстия перфорированной оболочки приллера", Вісник НТУ «ХПI», № 26 (1069), с. 186193, 2014.

[7] S. V. Shorin, N. V. Ksandrov, and G. V. Pastukhova, "Obtaining granulated complex fertilizers on base of carbamide and ammophos in high-speed drum granulator", Izvestiya Vysshikh Uchebnykh Zavedenii. Seriya Khimiya i Khimicheskaya Tekhnologiya, vol. 55, iss. 11, pp. 82-85, 2012.

[8] П. В. Серый, И. С. Бойко, С. В. Островский, и С. В. Лановецкий, "Исследования скорости роста кристалла карбамида", Молодежная наука в развитии регионов, c. 291-295, 2011

[9] Ю. А. Сергеев, Р. В. Андержанов, и А. А. Воробьёв, "Энерго-ресурсосберегающие технологии и оборудование в производстве карбамида", ОАО «Научноисследовательский $u$ проектный институт карбамида и продуктов органического синтеза», т. 62 (4), с. 28 33. 2018.

[10] I. М. Демчук, та Г. С. Столяренко, "Економічна оцінка ефективності впровадження технологій вторинної переробки відходів виробництв на прикладі утилізації азотовмісних стоків агрегату синтезу карбаміду", Збірник наукових праць Черкаського державного технологічного університету. Серія: Економічні науки, вип. 48, с. 37-44, 2017.

[11] I. Demchuk, H. Stolyarenko, N. Fomina, and V. Mikheyenko, "Conversion of N-containing compounds of flash steam condensate from carbamide production into hydrazine sulfate", Eastern-European Journal of Enterprise. Technologies. Technology of organic and inorganic substances, 1/6 (97), pp. 53-65, 2019.

[12] I. M. Demchuk, H. S. Stolyarenko, and N. I. Tupytska, "Recuperation of bound nitrogen by processing into hydrazine sulfate in industrial wastewater", Вісник Черкаського державного технологічного університету. Серія: Технічні науки, № 4, c. 114-120, 2016.

[13] I. М. Демчук, та Г. С. Столяренко, "Дослідження процесу синтезу гідразину в 
електромагнітному реакторі з конденсатів сокової пари виробництва карбаміду", Вісник Східноукраїнського начіонального університету імені Володимира Даля, № 7, с. 37-44, 2018.

[14] I. М. Демчук, та Г. С. Столяренко, "Аналіз параметричної стохастичної системи синтезу гідразин-сирця з вторинної сировини в хвильовому реакторі", Вісник Черкаського державного технологічного університету. Серія: Технічні науки, № 3, c. 27-33, 2018.

[15] С. А. Куценко, Н. В. Бутомо, А. Н. Гребенюк и др. Военная токсикология, радиобиология и медицинская защиита: учебник / под. ред. С. А. Куценко. СанктПетербург: Фолиант, 2004.

[16] Э. И. Абдурахманов, и М. Д. Саттарова, "Полупроводниковый сенсор гидразина", Вестник науки и образования. Серия: Научно-методический журнал, вып. 2, с. 9$13,2015$.

[17] Л. А. Иванова, "Влияние ракетного топлива на организм человека на объектах его использования, хранения и утилизации", Передовые технологии в промышленность, вып. 3, с. 153-158, 2015.

[18] А. Я. Самуилов, А. Р. Бариев, Н. В. Савин, Д. Р. Алекбаев, Н. Н. Шишкина, и Я. Д. Самуилов, "Перспективы организации новых производств в Республике Татарстан с использованием в качестве сырья карбамида", Вестник технологического университета, т. 19 (11), с. 96-100, 2016.

[19] I. М. Демчук,

Г. С. Столяренко, С. Ю. Кузнєцова, та Н. М. Фоміна, "Альтернативна технологія існуючих процесів очистки стічних вод виробництва карбаміду", на VI Міжнар. наук.-практ. конф. Чиста вода. Фундаментальні, прикладні та промислові аспекти, Київ: КП ім. І. Сікорського, 2019, с. 91-94.

[20] I. М. Демчук, "Аналіз впливу мікрохвильового випромінювання на процеси синтезу неорганічних та органічних сполук в електромагнітних реакторах", на Міжнар. наук.-практ. конф. Концептуальні напрями розвитку наукових знань (ч. III), Київ: МЦНД, 2018, с. 10-12.

[21] I. M. Demchuk, G. S. Stolyarenko, and S. Y. Kuznetsova, "Hydrazine sulfate technology out of urea production waste in the electromagnetic reactor", in Proc. VI Int.
Sci.-Pract. Conf. International Trends in Science and Technology. Warsaw, Poland, 2018, c. 14-20.

[22] N. H. Sabit, S. N. Abduljabbar et al., "Preparation of hydrazine hydrate from urea and sodium hypochlorite", Journal of Iraqi Industrial Research, vol. 4 (2), pp. 41-50, 2017.

\section{References}

[1] National report on the state of the environment in Ukraine in 2007, Kyiv, 2008 [in Ukrainian].

[2] Yu. A. Sergeyev, N. M. Kuznetsov, and A. V. Chirkov, Carbamide. Properties, production, application: monograph, Nizhniy Novgorod: Kvarts, 2015 [in Russian].

[3] S. V. Ostrovskiy, "Improving the technological scheme for the production of carbamide in order to reduce production losses of carbamide and raw materials", Vestnik Permskogo natsyonal'nogo issledovatel'skogo politekhnicheskogo universiteta. Khimicheskaya tekhnologiya i bilotekhnologiya, vol. 9, pp. 5-12, 2009 [in Russian].

[4] V. I. Petrov, R. R. Mad'yarov, R. R. Khayrulin, and I. M. Ayupov, "Analysis of technological schemes for the production of carbamide", Vestnik tekhnologicheskogo universiteta, vol. 18, no. 8, pp. 148-150, 2015 [in Russian].

[5] I. Shingareva, and C. Lizarraga-Celaya, Solving nonlinear partial differential equations with Maple and Mathematica: textbook. New York: Springer Wien, 2011.

[6] M. S. Skidanenko, V. I. Sklabinskiy, and N. P. Kononenko, "Study of the outflow of a liquid stream from the hole of a perforated priller shell", Visnik NTU «KhPÍ», no. 26 (1069), pp. 186-193, 2014 [in Russian].

[7] S. V. Shorin, N. V. Ksandrov, and G. V. Pastukhova, "Obtaining granulated complex fertilizers on base of carbamide and ammophos in high-speed drum granulator", Izvestiya Vysshikh Uchebnykh Zavedenii. Seriya Khimiya i Khimicheskaya Tekhnologiya, vol. 55, iss. 11, pp. 82-85, 2012.

[8] P. V. Seryy, I. S. Boyko, S. V. Ostrovskiy, and S. V. Lanovetskiy "Investigation of the growth rate of a carbamide crystal", Molodezhnaya nauka $v$ razvitii regionov, pp. 291-295, 2011 [in Russian]. 
[9] Yu. A. Sergeyev, R. V. Anderzhanov, and A. A. Vorob'yov, "Energy and resourcesaving technologies and equipment in the production of carbamide", OAO "Nauchnoissledovatel'skiy $i$ proyektnyy institut karbamida $i$ produktov organicheskogo sinteza", vol. 62, no. 4, pp. 28-33, 2018 [in Russian].

[10] I. M. Demchuk, and H. S. Stolyarenko, "Economic estimation of efficiency of introduction of technologies of secondary processing of production wastes on the example of utilization of nitrogen-containing effluents of carbamide synthesis unit", Visnyk Cherkaskogo derzhavnogo tekhnolohichnogo universytetu. Seriya: Ekonomichni nauky, iss. 48, pp. 37-44, 2017 [in Ukrainian].

[11] I. Demchuk, H. Stolyarenko, N. Fomina, and V. Mikheyenko, "Conversion of Ncontaining compounds of flash steam condensate from carbamide production into hydrazine sulfate", Eastern-European Journal of Enterprise. Technologies. Technology of organic and inorganic substances, 1/6 (97), pp. 53-65, 2019.

[12] I. M. Demchuk, H. S. Stolyarenko, and N. I. Tupytska, "Recuperation of bound nitrogen by processing into hydrazine sulfate in industrial wastewater". Visnyk Cherkaskogo derzhavnogo tekhnolohichnogo universytetu, no. 4, pp. 114-120, 2016.

[13] I. M. Demchuk, and H. S. Stolyarenko, "Investigation of the hydrazine synthesis process in an electromagnetic reactor from the condensates of the steam of carbamide production", Visnyk Skhidnoukrayins'koho natsional'noho universytetu imeni Volodymyra Dalya, no. 7, pp. 37-44, 2018 [in Ukrainian].

[14] I. M. Demchuk, and H. S. Stolyarenko, "Analysis of parametric stochastic system of synthesis of hydrazine-raw material from secondary raw material in a wave reactor", Visnyk Cherkaskogo derzhavnogo tekhnolohichnogo universytetu, no. 3 , pp. 27-33, 2018 [in Ukrainian].

[15] S. A. Kutsenko, N. V. Butomo, A. N. Grebenyuk et al, Military toxicology, radiobiology and medical protection: textbook. St. Petersburg: Foliant, 2004 [in Russian].

[16] E. I. Abdurakhmanov, and M. D. Sattarova, "Semiconductor sensor of hydrazine", Vestnik nauki $i$ obrazovaniya. Seriya: Nauchno-metodicheskiy zhurnal, no. 2, pp. 9-13, 2015 [in Russian].

[17] L. A. Ivanova, "The influence of rocket fuel on the human body at the objects of its use, storage and disposal", Peredovyye tekhnologii $v$ promyshlennost', no. 3, pp. 153-158, 2015 [in Russian].

[18] A. Ya. Samuilov, A. R. Bariyev, N. V. Savin, D. R. Alekbayev, N. N. Shyshkina, and Ya. D. Samuilov, "Prospects for the organization of new industries in the Republic of Tatarstan using carbamide", Vestnik tekhnologicheskogo universiteta, vol. 19, no. 11, pp. 96-100, 2016 [in Russian].

[19] I. M. Demchuk, H. S. Stolyarenko, S. Yu. Kuznyetsova, and N. M. Fomina, "Iternative technology for existing wastewater treatment processes for carbamide production", in VI Int. Sci.-Pract. Conf. Pure water. Fundamental, applied and industrial aspects, Kyiv: KPI im. I. Sikors'koho, 2019, pp. 91-94 [in Ukrainian].

[20] I. M. Demchuk, "The analysis of the influence of microwave radiation on the processes of synthesis of inorganic and organic compounds in electromagnetic reactors", in Int. Sci.-Pract. Conf. Conceptual directions of scientific knowledge development (part III), Kyiv: MTsND, 2018, pp. 1012 [ in Ukrainian].

[21] I. M. Demchuk， G. S. Stolyarenko， and S. Yu. Kuznetsova, "Hydrazine sulfate technology out of urea production waste in the electromagnetic reactor", in Proc. VI Int. Sci.-Pract. Conf. International Trends in Science and Technology, Warsaw, Poland, 2018, pp. 14-20.

[22] N. H. Sabit, S. N. Abduljabbar et al., "Preparation of hydrazine hydrate from urea and sodium hypochlorite", Journal of Iraqi Industrial Research, vol. 4(2), pp. 41-50, 2017. 


\author{
I. M. Demchuk, Ph. D., assistant, \\ e-mail: ivannademcuk19@gmail.com \\ H. S. Stolyarenko, D.Tech.Sc., professor, \\ head of chemical technologies and water purification department, \\ e-mail: radikal@ukr.net \\ V. M. Vyazovik, D.Tech.Sc. assistant professor \\ e-mail: v.viazovyk@chdtu.edu.ua \\ Cherkasy State Technological University \\ Shevchenko blvd, 460, Cherkasy, 18006, Ukraine

\section{HYDRAZINE SYNTHESIS AS A METHOD OF PURIFICATION OF CARBAMIDE PRODUCTION EFFLUENTS}

Today, the search of promising directions of production improvement is an urgent task. In the process of carbamide synthesis, up to $1.5 \mathrm{~m}^{3}$ of wastewater per ton of product is formed. Steam condensate formed during the concentration of a carbamide solution in vacuum evaporators is the main part of the effluent. For purification, the effluent is sent to a hydrolyzer for the hydrolysis of carbamide. Next, a desorption of ammonia and carbon dioxide occurs. Sewage containing bound nitrogen compounds for further treatment are sent to biological treatment facilities. The effectiveness of biological purification does not exceed $80 \%$. The aforementioned method of wastewater treatment requires high costs of electric and thermal energy. Hydrolysis and desorption of juice condensate are estimated as the most modern and most promising way of waste disposal. This method is implemented in all plants for the synthesis of carbamide.

The article considers a new method for the utilization of nitrogen-containing condensates of carbanide production by using them as secondary raw materials for hydrazine synthesis. A study of the synthesis of hydrazine in an electromagnetic synthesis reactor has been carried out. The effect of the flow rate of the reaction mixture entering the electromagnetic $\mathrm{N}_{2} \mathrm{H}_{4}$ synthesis reactor on the product yield has been studied. The dependence of the degree of conversion of total nitrogen to $\mathrm{N}_{2} \mathrm{H}_{4}$ on the flow rate of the reaction mixture into a multimode electromagnetic hydrazine synthesis reactor is established. Experimentally obtained data are mathematically processed in order to establish the optimal flow regime. The results of calculating the mathematical model of the kinetics of chemical reactions initiated by electromagnetic heating are confirmed by solving the system of Arrhenius equations and thermal conductivity in an implicit scheme. It has been confirmed that cyclic heating of the reaction mixture is more effective. In the course of studies, it is found that the synthesis of hydrazine proceeds in the diffusion area. Despite the fact that the absence of pumps reduces the energy consumption of a hydrazine synthesis plant from secondary raw materials, it is difficult to control the production process when introduced into production. The phenomenon of spontaneous regulation of the rate of removal of the synthesis solution from the reaction zone is initiated by the effects of internal airlift by $\mathrm{CO}_{2}$ gas and implosion.

Keywords: hydrazine, carbamide, ammonia, synthesis, condensate, electromagnetic reactor.

Стаття надійшла 09.01.2020

Прийнято 29.01.2020 